九州大学学術情報リポジトリ

Kyushu University Institutional Repository

\title{
A Marine Fauna from the Liutang Series of the Niuhsintai Coal-Field, South Manchuria
}

Noda, Mitsuo

Geological Institute, The 2nd Branch School of Kyushu University

https://doi.org/10.5109/1524110

出版情報：九州大學理學部紀要：Series D, Geology. 4 (1)，pp.99-105，1954-06-30. Faculty of Science, Kyushu University

バージョン：

権利関係 : 
Mem., Fac. Sci., Kyushu Univ., Ser. D, Vol. IV, No. 1, pp. 99-105.

\title{
A Marine Fauna from the Liutang Series of the Niuhsintai Coal-Field, South Manchuria
}

\author{
By
}

\section{Mitsuo NODA*}

The lower and upper coal-bearing formations in the Taitzuho (River Taitzu) district, the Huangchi series of Sakmarian and the Liutang series of Lower Rotliegendes respectively, contain several workable coal seams and many plant fossils. Concerning the ecological condition of their deposition, T. OGurA ${ }^{(24)}$ and the present writer $(15,18,19)$ pointed out that these series are not completely continental and the coal seams may be littoral, accompanying some inter-coal formations of marine origin. OGURA discovered a marine siliceous Foraminifera (Ammodiscus sp.) in the shale immediately under the Paotsa coal seam of the Liutang series in Penhsihu, together with many remains of Radiolaria, Sponge spicules and Foraminifera (Nodosinella sp.) from the shale (and nodules in it) under- and overlying the Ichieh coal seam of the Huangchi series in Penhsihu. The similar fossils are found also in the shale (and nodules in it) overlying the Sanchich coal seam of the same series in Yentai. The writer discovered also four layers of thin black limestone, $20-50 \mathrm{~cm}$ in thickness, in the black shale of about $5 \mathrm{~m}$ thick resting upon the lowermost coal seam of the Huangchi series in the southern part of Chuanchiaputzu in the Tienshihfu coal-field, in which abundant minute Gastropods such as Sphaerodoma rendoi NoDA, Sph. sp. and Naticopsis sp. have been imbedded. N. KoBATAKE ${ }^{(12)}$ concluded that these limestones belong to the Lower Jurassic in age, and that the boundary between the black shale and underlying Huangchi coal seam may be over-thrust. But according to the writer's reinvestigation, over-thrust cannot be recognized in that locality of over-thrust reported by КоватAке. Moreover some Palaeozoic plant fossils such as Cordaites sp. and Stigmaria sp. were found in the gray sandstone, which is intercalated in the black shale of a horizon of about $20 \mathrm{~m}$ upper from the uppermost stratum of limestone. Evidences so far available indicate that the limestones undoubtedly belong to the Huangchi series.

Some years ago, the writer collected many interesting fossils of marine Brachiopods, which are well preserved in general, together with some other ones, from the dark gray shale of the lower part of the Liutang series in a valley of the west of Hsiaonankou in the Niuhsintai coal-field. The fauna is distinctive, comprising the following species :

Brachiopoda

\footnotetext{
* Geological Institute, The 2nd Branch School of Kyushu Uyushu University, Kurume.
} 
1. Chonetes latesinuata SchelrwiEN

2. Ch. pygmaea LoczY

3. Ch. substrophomenoides HuANG

4. Ch. spp.

5. Waagenoconcha cfr. purdoni (DAvIDSON)

6. Productus taiyuanfuensis $\mathrm{G}_{\mathrm{RABAU}}$

7. $P$. gruenewaldti Krotow

8. Marginifera pusilla Scher.LWIEN

9. Linoproductus koninchianus (VERNEUIL)

10. $L$. sp.

11. Striatifera sp.

12. Schellwienella regularis HUANG

13. Sch. sp.

Pelecypoda

14. Aviculopecten manchuriensis $\mathrm{CHAO}$

15. Lima striatoplicata CHAO

16. Nuclopsis sp.

Gastropoda

17. Paromphalus cfr. mapingensis GRABAU

Cephalopoda

18. Orthoceras? sp.

19. Apheloceras sp.

Anthozoa

20. Gen. sp. indet.

Crinoidea

21. Gen. sp. indet.

Geological ages of 12 species which are specifically identified as shown above are discussed below.

Chonetes latesinuata was first described by Schellwien (26) from the "Fusulinenkalk" of the Carnic Alps. $\mathrm{CHAO}^{(3)}$ found abundantly this species in the Taiyuan series of Kansu, Shansi, Hopei and Honan. GrabaU (7) introduced another specific name Ch.nyströmi for a group of shells from the same series of North China, which, in the opinion of the writer, is synonymous to the Schellwien's species. The writer $(16,17)$ also reported $C h$. latesinuata from the Atung series of the east of Tingchiatun in the Fuchou (Wuhutsui) coal-field, and from the Hunglohsien series at Pingtingshan, south of Yangchiachangtzu, Chinsi-hsien. In Niuhsintai, this species is rather common and well preserved.

Chonetes pygmaea in Russia is not only a characteristic form of the Moscovian stage, but extends in age up to the Cora and Pseudoschwagerina stage as well. In North China, this species has essentially the same vertical range as the Russian form, 
being found both in Moscovian Penhsi series and in the Sakmarian Taiyuan formation. According to $\mathrm{CHAO}^{(3)}$ the species occurs in the Yanghukou limestone of the Penhsi series at Yanghukou, Shantan-hsien, Kansu, and in a shaly bed of the Taiyuan series at Hsikou-Chienyao of the same district. In Shansi, it was found in the Kuantikou limestone of the east of Taiyuan. In Hopei, it was obtained from a dark limestone exposed just beside the Lincheng coal mine, where it is in association with Marginifera pusilla, Ch. latesinuata and the other species of the typical Sakmarian Taiyuan fauna. In Niushsintai, it is also rather abundant.

Chonetes substrophomenoides was originally described by HUANG(10) from the Lyttonia bed of the Middle Permian age, at Panshan, Tungtzu-hsien and Pichiehhsien, Kueichou. The species from Niuhsintai is represented by two shells, that is, one pedicle valve, the other branchial valve.

Waagenoconcha purdoni, though not abundant, is widely distributed in the Carboniferous and Permian formations of India, ${ }^{(4)}$ Himalaya, ${ }^{(5)}$ Spitzbergen, ${ }^{(30)}$ Mongolia ${ }^{(3,8)}$ and the others. The Mongolian form is represented by a single specimen from the

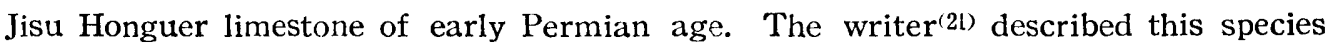
from the Lower Permian sandstone at Yuchuan (Erhtsengtientzu), east of Harbin. The shell from Niuhsintai, however, is imperfect and needs of additional data for its positive identification.

Productus taiyuanfuensis is one of the most abundant and wide-spread Productus in the Taiyuan and Shansi series of North China. Wherever marine Permian strata are exposed, this Productus species is often innumerablly found. According to CHAO(3) and $\mathrm{O}_{Z A K I}{ }^{(25)}$ it occurs in the marine beds of the Taiyuan series, for instance in Kuantikou limestone near Kuantikou village, east of Taiyuan; the Pankou, Miaokou, Maoerhkou and Hsiehtao limestones in the western district of 'Taiyuan; the Houkou limestone of the Lincheng coal-field, Hopei; all the limestone at different localities of the Tse-hsien and Liuhokou coal-field; a shale layer at the base of the Yangchiatun coal series, Western Hills of Peiching; the Tangshan limestone and a marine bed of an upper horizon of the Kaiping Basin; the marine beds of Hsin-an-hsien, Honan and the Poshan coal-field, Shantung. It is by far the most common in the Tuntayao limestone, the Paotechou limestone and the Tumen shale of the Shansi series in central and western Shansi. The writer ${ }^{(20)}$ observed a large amount of remains of this species in the limestone of the Taiyuan series at the Laiwu coal-field, Shantung. It occurs also in the Permian formations, especially in the Sakmarian strata, such as the Atung and Hunglohsien series of Manchuria. Namely, it was found in the Atung series of the Fuchou coal-field by $\mathrm{CHAO}^{(3)}$ and the writer ${ }^{(16,17)}$ who also found it in the Hunglohsien series of Pintingshan, south of Yangchiachangtzu. It is moreover found in the Lamakou shale of the Hsinglung coal-field, Jehol, ${ }^{(22,23)}$ which may be correlated to the Taiyuan series. In Niuhsintai, this species predominates, though it is more or less incompletely preserved. 
Productus gruenewaldti is an important and wide-spread species in the Lower Permian of Asia. In Ural and Timan, it first appears in the Cora-horizon and extends up to the Artinskian.(13) Schell.wien ${ }^{(26)}$ described it under the name of $\mathrm{Pr}$. semireticulatus var. bathykolpus from the Fusulinenkalk of the Carnic Alps. MAnsuY(14) reported it from the Productus limestone of Indochina, while $\mathrm{CHAO}^{(3)}$ noted that the species is entirely restricted in North China to the Moscovian Penhsi series. Ozaki ${ }^{(25)}$ described it from an unknown horizon at Mingshankou, Penhsihu, which should be, the writer considers, obtained from the limestone of the Penhsi series. $\mathrm{GRABAU}^{(9)}$ also reported it from the Maping limestone of Kuangsi and Kueichou. The Maping limestone is exactly equivalent to the the Chuanshan limestone of South China and the Taiyuan series of North China. In Niuhsintai, it is rather common, though its preservation is bad in general.

Marginifera pusilla was originally described by SchellwweN (26) from the Fusulinenkalk of the Carnic Alps. Later on, KIEDEL (11) also reported it from the Upper Palaeozoic sediments of South Tienshan. According to $\mathrm{CHAO}^{(1,3)}$ it is a very characteristic and wide-spread species in the Taiyuan series of North China. It occurs abundantly in the Miaokou, Maoerhkou and Hsiehtao limestones of Shansi, in the Hokou limestone just beside the Lincheng coal mine, Hopei; all the five limestone beds (Taching, Hsiaoching, Fuching, Shanching and Yehching) exposed at different localities of the Tze-hsien coal-field, Hopei; a limestone of the Taiyuan series in the Changchiu coal-field, Shantung; Taching limertone of the Liuhokou coal-field, Honan; and in the Sinho formation at Sinho, Shantan-hsien, Kansu. In Niuhsintai, it is represented by abundant well preserved shell.

Linoproductus koninchianus was first reported from the Pseudoschwagerina limestone of Russia. (27) GrABAU ${ }^{(9)}$ noted it from the Maping limestone of Kueichou. In North China, though the species is rather rare in the Taiyuan series, it was described by $\mathrm{CHAO}^{(3)}$ from a dark limestone of the Taiyuan series in the Lincheng coal-field, Hopei ; and the Kuantikou and Maoerhkou limestones, east and west of Taiyuan, respectively.

Schellwienella regularis was obtained by $\mathrm{HUANG}^{(10)}$ from the Lyttonia nobilis horizon of the Permian coal-bearing formation of Pichieh-hsien, Kueichou, and from the Lyttonia bed at Panshan, Tungtzu-hsien, Kueichou. In Niuhsintai, it is represented by two brachial valves.

Aviculopecten manchuriensis was found by $\mathrm{CHAO}^{(2)}$ in the Atung series at Yanshukou in the Fuchou coal-field and the Kuantikou limestone of Taiyuan in Shansi. The species from Niuhsintai is represented by a single specimen.

Lima striatoplicata occurs in the Spirifer taiyuanensis zone of the Taiyuan series. It was obtained by $\mathrm{CHAO}^{(2)}$ from the Miaokou and Kuantikou limestones at Taiyuan, Shansi. In Niuhsintai, two specimens identified to this species were found.

Paromphalus mapingensis was obtained by $\mathrm{GrABAU}^{(9)}$ in the the Maping 
limestone of Kueichou. In Niuhsintai, a single, imperfect specimen of this species was collected.

As stated above, one of the striking features of this fauna is that the common species in the Taiyuan series of North China are found in comparatively abundant. The Maping series of South China and the Atung series of South Manchuria, however, are especially noteworthy since they have another characteristic feature of this fauna, in having the characteristic species of Lyttonia bed of South China, such as Chonetes substrophomenoides HUA: the indications as above mentioned, the geological age as shown by the faunal evidence of the Liutang series is considered to not be conflicting with the conclusion from the standpoint of the floral evidences that this series should belong to the Lower Rotliegendes. The marine fossils from the Liutang series not only indicates conclusive data concerning the ecological condition of the deposition of this series, as it has been confirmed by OGURA and the writer, but also reveals a criterion showing the geological age and the correlation of the Liutang series, as well as the latest marine transgression in South Manchuria.

In conclusin, the writer wishes to offer his cordial thanks to Prof. Iwao TAteiwa of Tokyo University for his kindness in reviewing the manuscript.

\section{Chinese geographical names referred to in this report.}

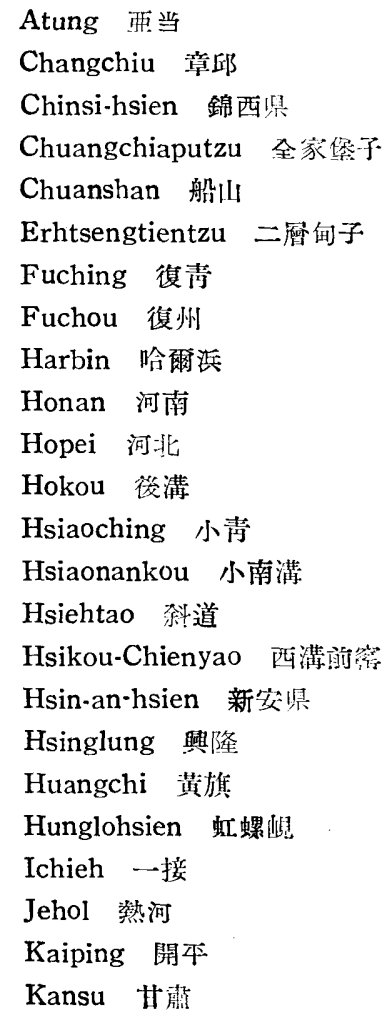

Atung 亜当

Changchiu 章邱

Chinsi-hsien 錦西哭

Chuangchiaputzu 全家佂子

船门

Fuching 復䠋

Fuchou 復州

Harbin 哈爾浜

Honan 河南

Hopei 河北

Hokou 後溝

Hsiaonankou 小南溝

Hsiehtao 斜道

Hsikou-Chienyao 西满放窄

Hsin-an-hsien 新客埧

Hsinglung 興隆

Huangchi 黄旗

Hunglohsien 虹螺岾

Ichieh 一接

Jehol 熱河

Kaiping 開4

Kansu 莳肃

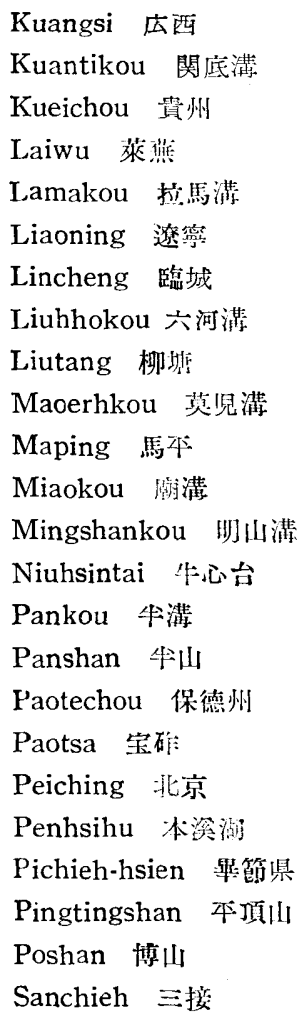

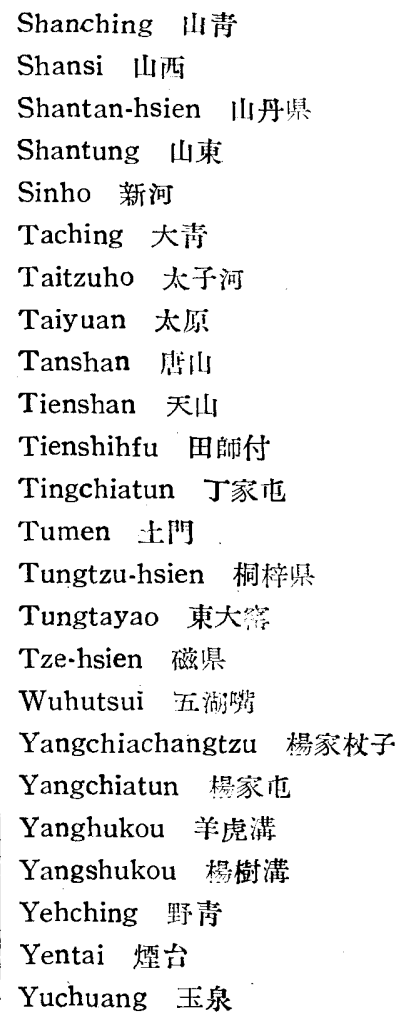




\section{References}

(1) Chao, Y. T.: 1926. On the Age of the Taiyuan Series of North China; Bull. Geol. Soc. China, Vol. IV, Nos. 3-4.

(2) _ - : 1927. Fauna of the Taiyuan Formation of North China-Pelecypoda; Pal. Sin. Ser. B, Vol. IX, fasc. 3.

(3) : 1927-28. Productidae of China, Pt. I-II, Ibid. Vol. V, fasc. 2-3.

(4) Davidson, T.: 1862. On Some Carboniferous Brachiopoda, Collected in India by A. Fleming and W. PURDON; Quar. Jour. Geol. Soc. London, XVIII.

( 5 ) Diener, C.: 1897. Permian Fossils of the Productus Shales of Kumaon and Gurhwal; Himalaya Fossils; Pal. Ind. Ser. XV, Vol. I, Pt. 4.

(6) Frech, F: 1911. Das Carbon Chinas; in F. v. Richthofen, China, Vol. V.

(7) Grabau, A. W.: 1927. Stratigraphy of China, Pt. 1.

(8) — - : 1931. The Permian of Mongolia.

(9) — : 1936. Early Permian Fossils of China, Pt. II ; Fauna of the Maping Limestone of Kwangsi and Kueichow; Pal. Sin. Ser. B, Vol. VIIl, fasc. 4.

(10) Huang, C.: 1932-33. Late Permian Brachiopoda of Southwestern China, Pt. I-II, Ibid., Vol. IX, Fasc. 1-2.

(11) KIEDEL, H.: 1906. Geologische Untersuchungen in südlichen Tian-Shan nebst Beschreibung einer obercarbonischen Brachiopodenfauna aus dem Kukurtuk-Tal ; Neu. Jahrb. für Miner. etc., Beilage Bd. 22.

(12) Kobatake, N.: 1942. Geology of the Vicinity of the Tienhsihfu Coal-Field (in Japanese); Bull. Geol. Inst. Manch., No. 106.

(13) Loczy, L.: 1899. Wissenschaftliche Ergabnisse der Reise des Grafen Béla Széchenyi in Ostasien; Bd. III.

(14) Mansuy, H.: 1913. Faunes des Calcaires à Productus de l'Indochine; Mém. Surv. Géol. Indochine, Vol. II, fasc. 4.

(15) NoDA, M.: 1939. Stratigraphical Studies on the Carboniferous and Permian Systems of South Manchuria (in Japanese, with English Resume); Bull. Cent. Nat. Mus. Manch., No. 1.

(16) _ _ 1940. On the Geology of the Upper Palaeozoic Coal-Fields in the Chinchou Province (in Japanese, with English Resume); Ibid., No. 2.

(17) ___ : 1942. Carboniferous-Permian Boundary in the Fuchou Coal-Field, Southern Manchoukuo; Ibid.، No. 3.

(18) - 1942. On the Boundary between the Carboniferous and Permian Systems in the Taitzuho District (in Japanese, with English Resume), Ibid., No. 4.

(19) - 1942. On a New Species of Sphaerodoma from the Tienhsifu Coal-Field, Fengtien Province, Manchoukuo; Ibid., No. 4.

(20) _ - : 1944. Geology of the Central Part of the Laiwu Coal-Field, Shantung Province (in Japanese); Ibid, No. 7.

(21) - : 1951. A Lower Permian Fauna from North Manchuria ; Jour. Geol. Soc. Japan, Vol. 57, No. 666 .

(22) __ and Kinara, T. 1951. The Order of Succession and Fossils of the Hsinglung Coal.Field, Jehol Province (in Japanese); Ibid., Vol. 57, No. 57.

(23) Nonaka, J.: 1944. On the Occurrence of Permian Marine Shells in the Hsinglung CoalField in Jehol; Ibid, Vol. 51, No. 609.

(24) OGura. T.: 1935. The Coal-bearing Beds of Penhsihu and Yentai are the Continental Deposits, or not? (in Japanese); Ibid., Vol. 42, No. 497.

(25) OzAKI, K.: 1931. Upper Carboniferous Brachiopoda from North China; Bull. Shanghai Sci. Inst., Vol. 1, No. 6.

(26) Schellwien, E.: 1892. Die Fauna des karnischen Fusulinenkalks, I; Pal.-gr. Vol. 39,

(27) TSCHERNYSCHEW, T.: 1902. Die oberkarbonischen Brachiopoden des Ural und des Timan; Mém. Comm. Géol. Russe, Vol. XVI, No. 2, 
(28) Verneuil, E.: 1845. The Geology of Russia in Europe, and the Geology of the Ural Mountains; Vols. I-II.

(29) WaAgen, W.: 1884. Salt Range Fossils ; Pal. Ind., Ser. XIII, Vol. 1, Productus Limestone Fossils, Pt. 4.

(30) Wiman, C.: 1914. Über die Karbonbrachiopoden Spitzbergen und Bären.Eilands. 